\title{
Effects of Sand Preparation Techniques on the Performance of Bio-Sand Filter
}

\author{
M. K. Ketter ${ }^{\mathrm{a}}$, Njenga Mburu ${ }^{\mathrm{a}}$

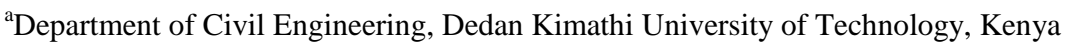

\begin{abstract}
The study sought to evaluate the effects of sand preparation techniques on the performance of bio-sand filter. Four bio-sand filter prototypes were constructed and filled with sand prepared through various techniques. The preparation techniques of the sand were (a) washing with treated water, (b) drying in the sun for a day, (c) drying in oven at $105^{\circ} \mathrm{C}$ and (d) soaking in chlorine. River water was applied in this study. Turbidity, Total Suspended Solid (TSS) and the Coliform tests were performed on the river water before and after passing through the bio-sand filter prototypes. The tests were done to evaluate the impact of sand preparation techniques on the efficiency of bio-sand filter in reducing turbidity, total suspended solids and Coliforms content. The results showed that all the sand preparation techniques generally reduce turbidity, total suspended solids and Coliforms content appreciably. However the soaked with chlorine prototype was the most efficient, with the removal efficiencies of $97.97 \%$ for Coliforms, $92.86 \%$ for TSS and $89.17 \%$ for Turbidity. Next was the sand washed with treated water prototype achieving removal efficiencies of $96.99 \%$ for Coliforms, $96.43 \%$ for TSS and $\mathbf{8 0 . 8 1 \% ~ f o r ~ T u r b i d i t y . ~ T h e ~ s t u d y ~ s h o w e d ~ t h a t ~ t h e ~ b i o - f i l t e r ~ s a n d ~ p r e p a r e d ~ b y ~ s o a k i n g ~ i n ~ c h l o r i n e ~ a c h i e v e d ~ t h e ~ h i g h e s t ~ r e m o v a l ~}$ efficiency.
\end{abstract}

Keywords: Bio-sand filter, sand preparation techniques, Turbidity, Coliforms, Total Suspended Solids

\section{Introduction}

Safe drinking water has been linked to improved human health and human development [1], [2]. Inadequate and unsafe water, poor sanitation, unsafe hygiene practice have been linked with causing diarrheal diseases that are responsible of at least 1.9 million deaths of children aged under 5 annually [1]. Although there is significant improved access to safe drinking water which has led to $27 \%$ reduction of child mortality from 1190-2008 [3] about 1.1 billion people still lack access to water [1], majority living in rural areas in developing countries.

In the developing countries, implementation of municipal water treatment system can be impractical and costly due budgetary constraints. Therefore, the consideration of low cost household water treatment systems is a reasonable alternative [4]. Bio-sand filter is one of the low cost household water treatment methods which has grown significantly in use over recent years as way of improving water quality in rural areas [5].

Bio-sand filter reduces pathogens in primary water sources in varying proportion [6-7] by formation of schmutzdeckeon the surface of the sand bed as the filtration progresses. The formation of schmutzdeckeis considered an important process influencing purification in the bio-sand filter [8]. Further, protozoa, bacterial, algae, and other forms of life within the filter bed contribute to pollutant removal [9]-[11] including E. coli [12].

The efficiency of purification in a bio-sand filter vary depending on the type of filter, choice of filter depth, sand type, sand grain size and the filtration rate[13]. Biological activity is enhanced with increasing filter depth, as microorganism and other suspended particles have to travel a longer through the sand, thus, a higher removal efficiency is expected with large sand depth [14].
The main component involved in the filtration process of biosand filter is the sand media. Currently, the method used in sand preparation for the bio-sand filter is simply cleaning with water [15]. This study sought to evaluate the effects of sand preparation techniques on the performance of bio-sand filter. The preparation techniques of the sand were (a) washing with treated water, (b) drying in the sun for a day, (c) drying in oven at $105^{\circ} \mathrm{C}$ and (d) soaking in chlorine. Materials and methods, results analysis and discussion, and conclusion have been dealt with in an elaborate manner in this paper.

\section{Materials and Methods}

\subsection{Filter Media Preparation}

This was done in accordance to Centre for Affordable Water and Sanitation Technology (CAWST) bio-sand filter manual [16]. The filter material used was fine river sand of minimum clay, loam and organic content. The sand was screened to remove some large size sand particles, washed with water before grading to remove any clay and dirt content.

Sieve analysis test for fine sand was conducted using vertically stacked sieves of sizes of $2 \mathrm{~mm}, 1 \mathrm{~mm}, 500 \mu \mathrm{m}, 250$ $\mu \mathrm{m}$ and $125 \mu \mathrm{m}$. Sieve analysis test for gravel was conducted in the same manner with sieves of the followings seizes of $8 \mathrm{~mm}, 4 \mathrm{~mm}$ and $2 \mathrm{~mm}$. The material retained on the $6 \mathrm{~mm}$ sieve was used as the drainage layer while the material retained on the $1 \mathrm{~mm}$ sieve was used as a separating layer while the material passing through $1 \mathrm{~mm}$ sieve was used as filtration sand.

Four separate samples of sand were prepared according to the following sand preparation techniques: (a) washing with treated water, (b) drying in the sun for a day, (c) drying in oven at $105^{\circ} \mathrm{C}$ and (d) soaking in chlorine. 


\section{International Journal of Science and Research (IJSR) \\ ISSN (Online): 2319-7064}

Index Copernicus Value (2013): 6.14 | Impact Factor (2014): 5.611

\subsection{Sources of Water}

The water used in the experiment was untreated river water. This water was tested and analyzed for Turbidity, Total Suspended Solids (TSS) and Coliforms.

\subsection{Filter Prototype}

Filter apparatus, Fig. 1 were locally fabricated in this study. It consists of a plastic (PVC) column of length $250 \mathrm{~mm}$ and diameter of $100 \mathrm{~mm}$. The depth of sand media in the column was $100 \mathrm{~mm}$, separating layer of $50 \mathrm{~mm}$, and an under drain layer of $50 \mathrm{~mm}$. The column was plugged with a rubber stopper at the bottom fitted with two glass tubes. Four biosand filter prototypes were set up each with sand media prepared were (a) washing with treated water, (b) drying in the sun for a day, (c) drying in oven at $105^{\circ} \mathrm{C}$ and (d) soaking in chlorine.

Treated water was passed through the bio-sand filters for twenty one days to ensure full maturity of the bio-layer (schmutzdecke) [11]. Thereafter, the river (raw) water was passed through the bio-sand filter and the filtrate was tested for turbidity, total suspended solids and coliforms for each filter prototype. The following annotations have been used throughout this paper to aid in the identification of these filtrates:
A-River (raw) water before filtration:
B. Filtrate from sand oven dried at high temperature $\left(105^{\circ} \mathrm{C}\right.$.
C- Filtrate from sand dried in sunlight for a day.
D-Filtrate from sand washed with treated water.
E. Filtrate from sand soaked in strong chlorine.

\subsection{Tests on raw water samples and the filtered samples}

The tests were done on raw water and the filtrates from each prototype. The following tests were done as recommended by Centre for Affordable Water and Sanitation Technology (CAWST) water quality testing training manual [17]:

1. Turbidity test- Turbidity test was done determine the efficiency of the sand samples in reducing turbidity.

2. Total suspended solids test-This test was done to determine the efficiency of the sand samples in reducing the total suspended solids.

3. Coliform test- This was done to determine the extent which sample sand filter can reduces coliforms contaminants in water.

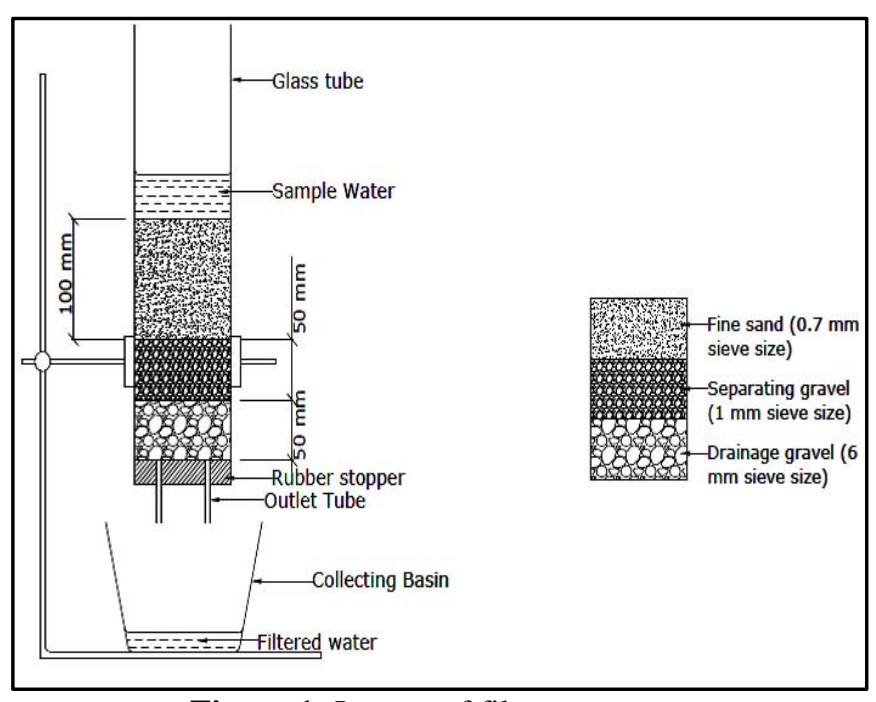

Figure 1: Layout of filter prototype

\section{Results, Analysis and Discussion}

\subsection{Sieve Analysis Test}

Sieve analysis test was performed on the sand to be used as the bio-sand layer in the prototype. The aim of this test was ensure that the effective size and uniformity coefficient was within the recommended values by CAWST [16]. The test was performed and the sieve analysis curve was plotted as shown in Fig. 2.It can be seen from Fig. 2 that the value of the effective size, $\left(\mathrm{D}_{10}\right)$ and uniformity coefficient, $\mathrm{Cu}$ is 0.25 and 2.8 respectively. The uniformity coefficient was within the recommended value of $\mathrm{Cu}<4$ for bio-sand filter [16].

\subsection{Turbidity Tests}

Turbidity test was performed on raw water and filtered water and the results were as shown in the Table 1. From Fig. 3, it can be seen that sample filtrate $\mathrm{E}$ (for sand cleaned with concentrated chlorine) had the least Turbidity of 2.42 NTU while the sun-dried and oven dried producing filtrate with highest Turbidity of 10.07 NTU and 8.28 NTU respectively. This could have been due to the fact that the sand sample was not cleaned using any form of liquid and hence leaving a lot of fine particles which could have made their way through the filtrate.

From Fig. 4, it can be concluded that the efficiency of biosand filter models in removing turbidity lies between 55-89\% with sample E (sand cleaned with chlorine) producing the highest efficiency of $89 \%$ higher than the rest including D (sand cleaned with treated water). This could be due the fact that chlorine corroded or dissolved organic material do to its corrosive property thus reducing the content. World Health Organization (WHO) recommends a Turbidity of $<5 \mathrm{NTU}$ for drinking water quality. This means that filtrates form sample $\mathrm{D}$ and $\mathrm{E}$ met the standards [18]. 
International Journal of Science and Research (IJSR)

ISSN (Online): 2319-7064

Index Copernicus Value (2013): 6.14 | Impact Factor (2014): 5.611

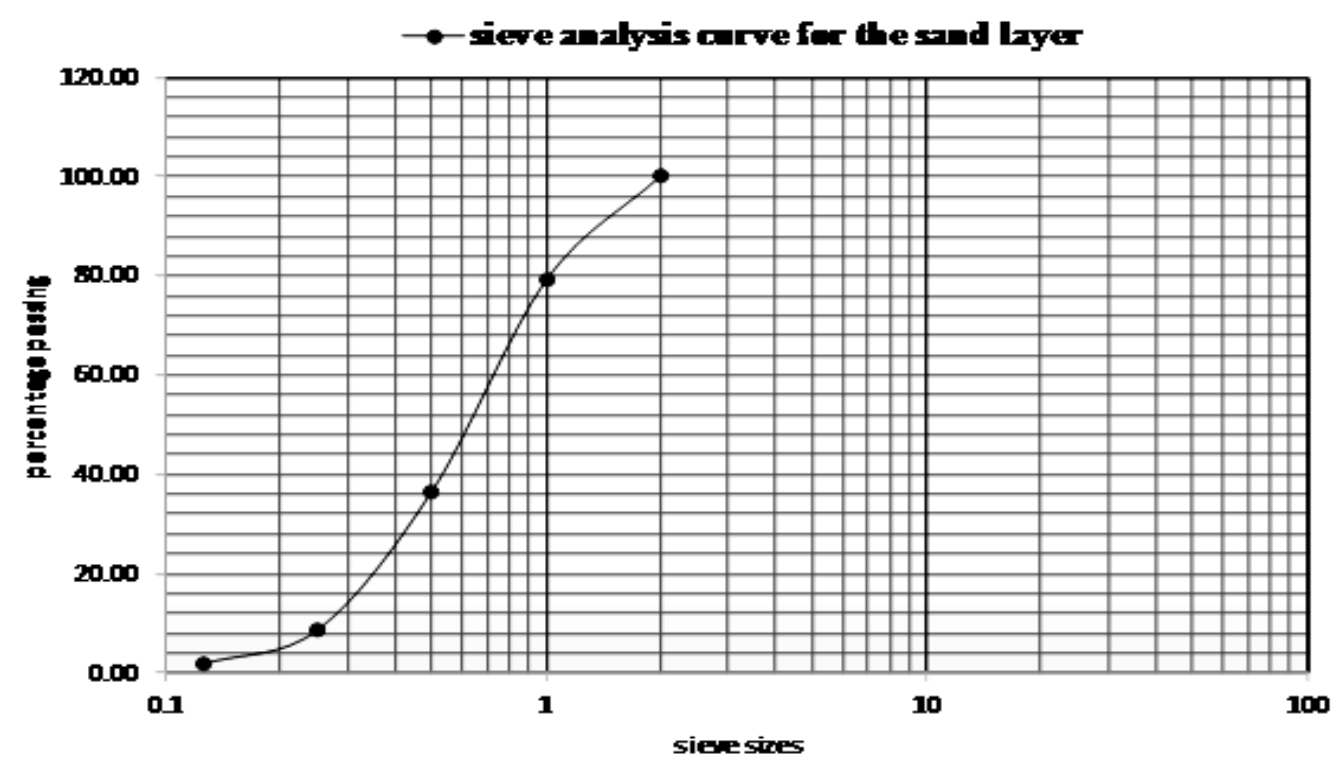

Figure 2: Sieve analysis curve for the sand

Table 1: Turbidity test results

\begin{tabular}{|c|c|c|}
\hline Samples & Turbidity (NTU) & Removal Efficiency (\%) \\
\hline A & 22.35 & \\
\hline B & 8.48 & 62.06 \\
\hline C & 10.07 & 54.94 \\
\hline D & 4.29 & 80.81 \\
\hline E & 2.42 & 89.17 \\
\hline
\end{tabular}

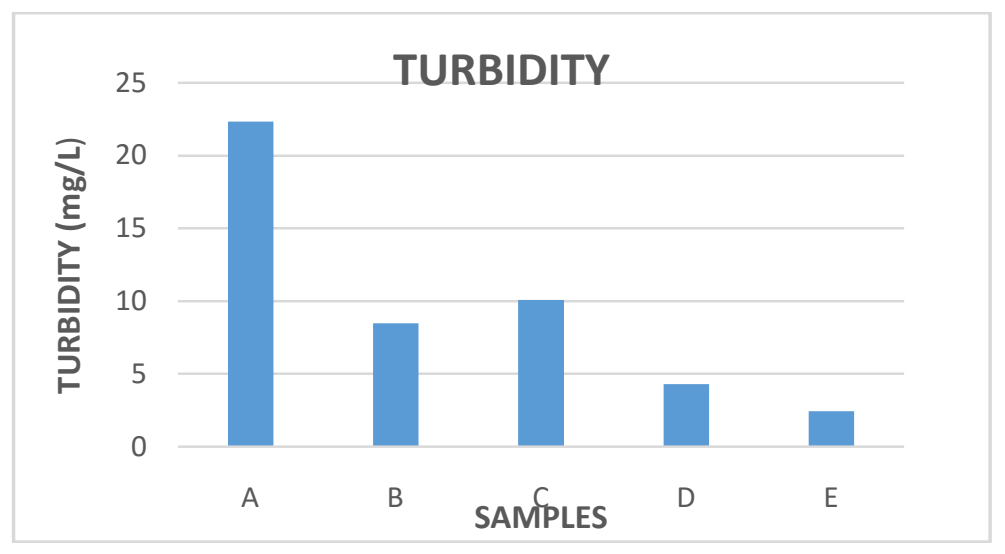

Figure 3: Turbidity present

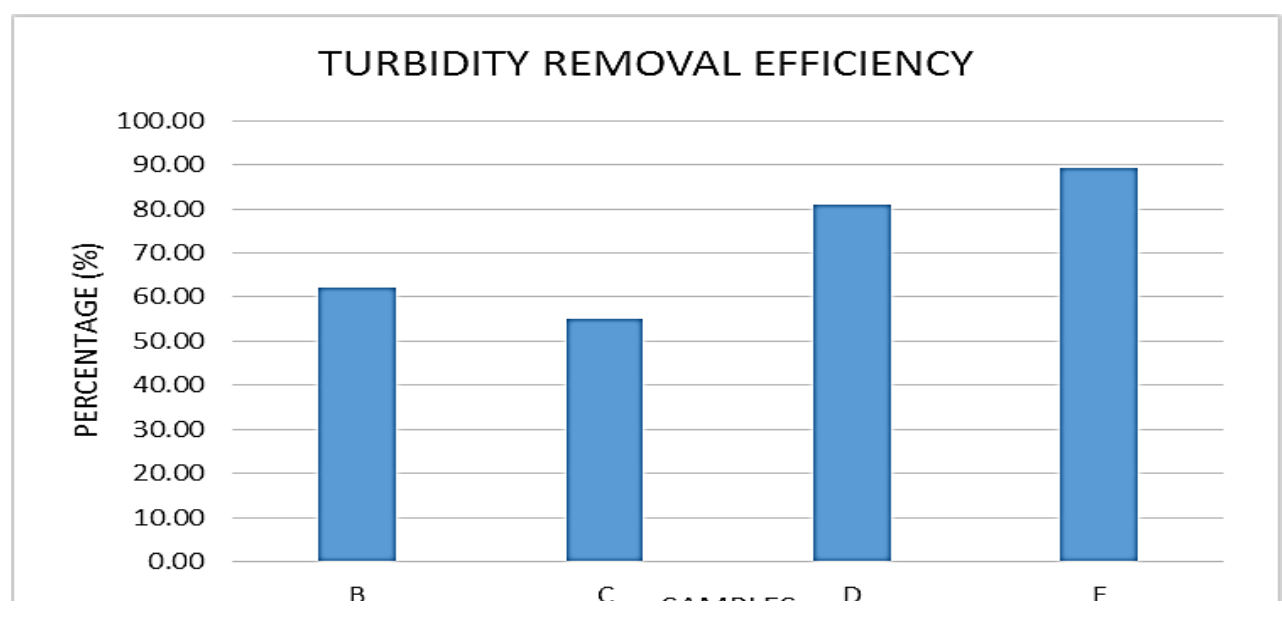

Figure 4: Turbidity removal efficiency

Volume 5 Issue 3, March 2016 www.ijsr.net 


\section{International Journal of Science and Research (IJSR) \\ ISSN (Online): 2319-7064}

Index Copernicus Value (2013): 6.14 | Impact Factor (2014): 5.611

\subsection{Total Suspended Solids Test}

The test involved finding the difference in weight of the oven dried filter papers before and after filtration. The results obtained were as shown in Table 2. From Fig. 5, it is evident that total suspended solids before filtration was extremely high which was $560 \mathrm{mg} / \mathrm{l}$. Oven dried sand and sun-dried sand produced high Total Suspended Solids in the filtrate of $80 \mathrm{mg} / \mathrm{l}$ and $100 \mathrm{mg} / \mathrm{l}$ respectively. Sand cleaned with water and chlorine produced the least Total Suspended Solid in the filtrates of $20 \mathrm{mg} / \mathrm{l}$ and $40 \mathrm{~mm} / \mathrm{l}$ respectively. Thus it can be concluded that sand cleaned using water or chlorine resulted in the removal of the very fine particles before installation in the prototype while sun-dried and oven-dried sand had a very fine particles in them and when installed in the filter some of the particles found their way into the filtrate. WHO guidelines [18] specifies that allowable value for Total Suspended Solids should be nil. Therefore, none of the samples met the guidelines.

As depicted in the Fig. 6, the Total Suspended Solids removal efficiency of the filters lied between $86 \%-96 \%$. Sample D (sand cleaned with water) had the highest total suspended solids removal efficiency which was $96,43 \%$. This shows that the sand undergoing some form of cleaning increases the efficiency of bio-sand filter in removing suspended solid.

Table 2: Total suspended solid test results

\begin{tabular}{|c|c|c|c|c|c|}
\hline Sample & $\begin{array}{c}\text { Weight of } \\
\text { dry filter } \\
\text { paper } \\
\text { (gms) }\end{array}$ & $\begin{array}{c}\text { Weight of } \\
\text { filter paper } \\
\text { with dried } \\
\text { sample } \\
\text { (gms) }\end{array}$ & $\begin{array}{c}\text { Weight } \\
\text { of TSS } \\
\text { (gms) }\end{array}$ & $\begin{array}{c}\text { TSS } \\
(\mathrm{mg} / \mathrm{l})\end{array}$ & $\begin{array}{c}\text { Removal } \\
\text { efficiency } \\
(\%)\end{array}$ \\
\hline A & 0.561 & 0.589 & 0.028 & 560 & \\
\hline B & 0.556 & 0.56 & 0.004 & 80 & 85.71 \\
\hline C & 0.569 & 0.574 & 0.005 & 100 & 82.14 \\
\hline D & 0.56 & 0.558 & 0.001 & 20 & 96.43 \\
\hline E & 0.545 & 0.547 & 0.002 & 40 & 92.86 \\
\hline
\end{tabular}

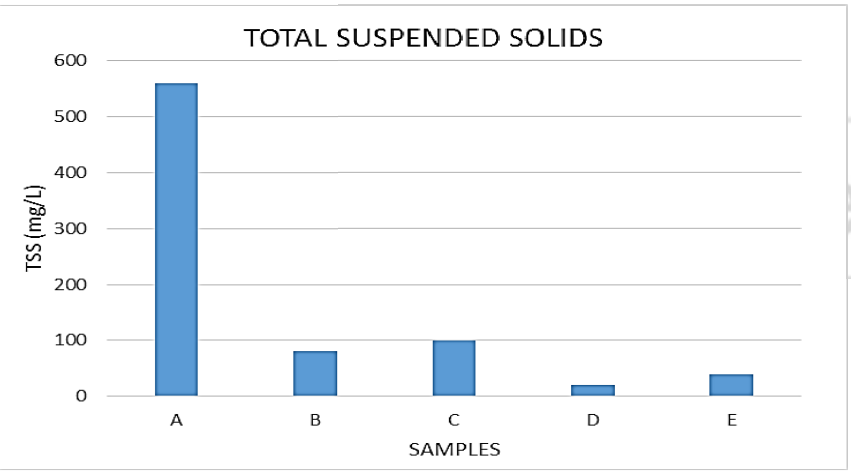

Figure 5: Total Suspended Solids present

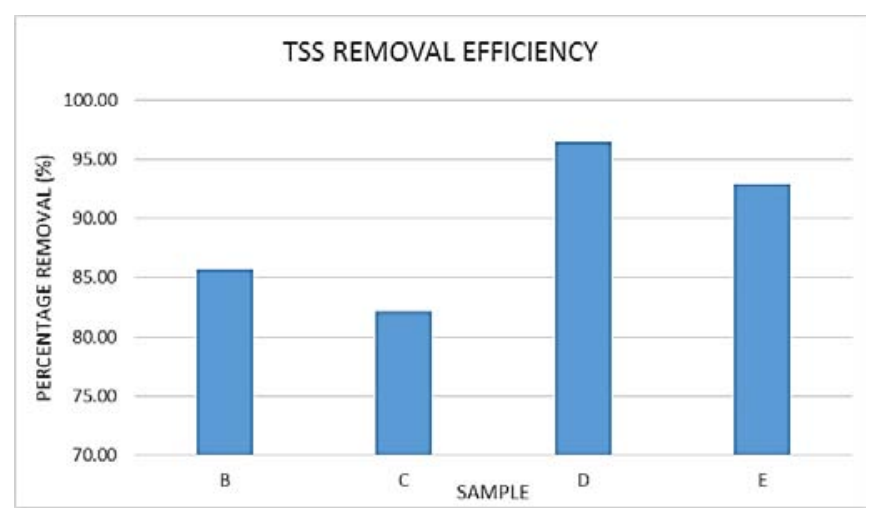

Figure 6: Total Suspended Solids removal efficiency

\subsection{Coliform Tests}

Multiple Tube Fermentation Technique (MPN) test was performed to determine the amount of Coliform counts in the raw water and filtrate. The results were as shown in Table 3.The microbial removal efficiency of the filter lied between 86\%-96\% (Fig. 7) with sun-dried having the least, $86.41 \%$ and chlorine cleaned having the highest efficiency, $97.97 \%$.

From Fig. 8 it can be seen that raw water before filtration had the highest Coliforms count of 1626 TC/100ml. which according to $\mathrm{WHO}[18]$ is categorized as very dangerous and should be rejected or must be treated thoroughly. The ovendried sand produced a filtrate with $141 \mathrm{TC} / 100 \mathrm{ml}$ while sundried sand produced a filtrate with $221 \mathrm{TC} / 100 \mathrm{ml}$. These samples fell within thin 101-1000TC/ml which WHO [18] defines as dangerous and must be treated. Sand cleaned with water produced a filtrate with $49 \mathrm{TC} / \mathrm{ml}$. The sand cleaned with chlorine produced the filtrate with the least Coliforms count of $33 \mathrm{TC} / \mathrm{ml}$. Coliforms count from D and E fell within the $11-100 \mathrm{TC} / 100 \mathrm{ml}$ which WHO [18] defines as polluted but can be consumed. Sand sample prepared using chlorine and treated water produced a tolerable amount of total Coliforms count compared to the rest of the sand preparation techniques.

\subsection{Relationship between turbidity and total Coliforms}

From Fig. 9, it can be seen that Turbidity and total Coliforms count have a direct relationship, the higher the Turbidity the higher the number of micro-organisms. This is due to the fact that highly turbid waters contain many colloidal particles on to which micro-organisms are attached.

Table 3: Coliform test results

\begin{tabular}{|c|c|c|}
\hline \multicolumn{3}{|c|}{ Total Coliform } \\
\hline Sample & $\begin{array}{c}\text { TC } \\
\text { (count/100 mls) }\end{array}$ & Microbial removal efficiency (\%) \\
\hline A & 1626 & \\
\hline B & 141 & 91.33 \\
\hline C & 221 & 86.41 \\
\hline D & 49 & 96.99 \\
\hline E & 33 & 97.97 \\
\hline
\end{tabular}




\section{International Journal of Science and Research (IJSR) \\ ISSN (Online): 2319-7064}

Index Copernicus Value (2013): 6.14 | Impact Factor (2014): 5.611

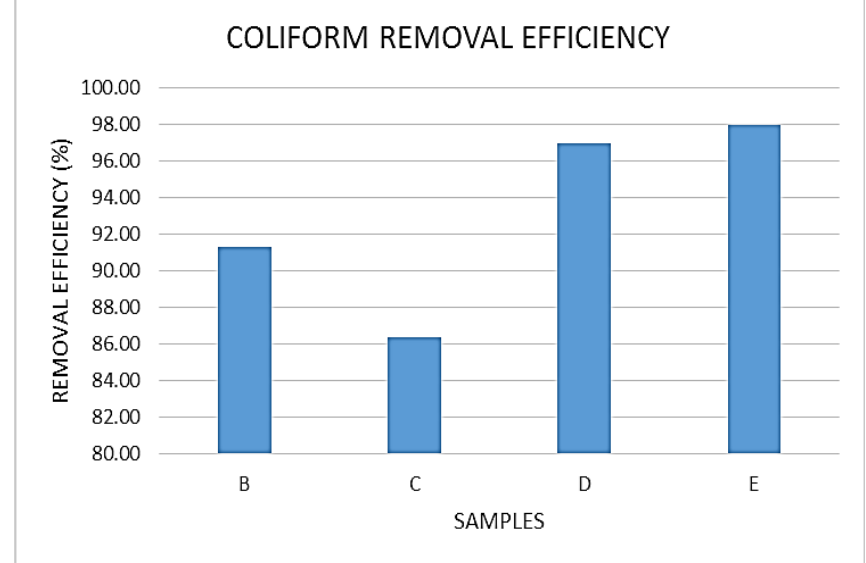

Figure 7: Coliforms removal efficiency

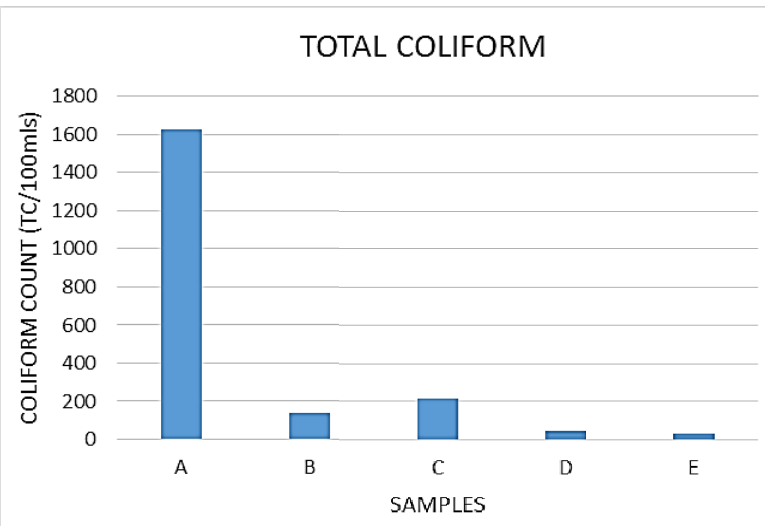

Figure 8: Coliforms present

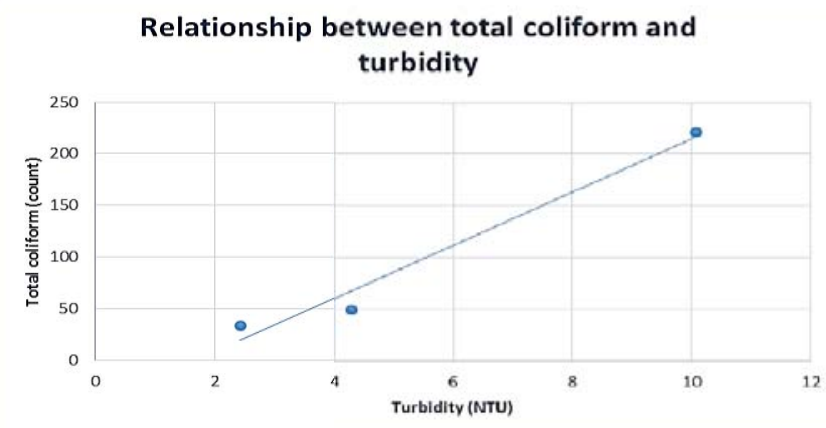

Figure 9: Relationship between total Coliform and turbidity

\section{Conclusion}

The following conclusions can be drawn from the study:

(a) The optimal sand preparation technique was cleaning with chlorine. It produced the highest efficiencies in turbidity removal and microbial removal of $89.17 \%$ and 97.97\%.

(b) The technique that involved cleaning with a liquid, water or chlorine, was more efficient in purifying the water as opposed to the techniques that relied on solar radiation or high oven temperatures only.

(c) There is need to investigate further on the removal of contaminants by sand prepared by washing with treated water and chlorine to ascertain the cause of the difference in the efficiency.

\section{Reference}

[1] United Nations, "Water, Sanitation and hygiene strategies for 2006 - 2015", UNICEF Economic and social Council, E/ICEF/2006/6, 2005.

[2] World Health Organization/United Nations Children' Fund, "Meeting the MDG drinking water and sanitation target: The urban and rural challenge of the decade", WHO, Geneva, 2006.

[3] World Health Organization, "World health statistics 2010", WHO, Geneva, 2010.

[4] Duke W, Mazumder A, Nordin R. \& Baker D., "The use and performance of Bio-sand Filters in the Artibonite Valley of Haiti: A field study of 107 households. Rural and Remote Health, 6:570, 2006.

[5] Clasen T. F. \& Cairncross S., "Household water management: refining the dominant paradigm", Tropical Medicine and International Health, Vol 9 (2), pp187191, 2004.

[6] Stauber C.E., G.M. Ortiz, K.R. Liang, B.A. Aiken and M.D. Sobsey, "The bio-sand filter: A robust and sustainable technology for household water treatment in developing countries", ISEE 20thAnnual conference, Pasadene, California, Epidemiology, 19 (6): 5296, 2008.

[7] Langenbach K, Kuschk P, Horn, H., \& Kastner, M., "Slow sand filtration of secondary clarifier effluent for wastewater reuse", Environmental Science \& Technology, 43(15), 5896-5901, 2009.

[8] Farooq, S. H, AlǦYousef A. K., AlĞLayla R. I., \& Ishaq A. M., "Tertiary treatment of sewage effluent via pilot scale slow sand filtration", Environmental Technology, 15(1), 15-28, 1994.

[9] Banda I., "Zimbabwe: Filtering fact from fiction about D.I.Y. water treatment", Inter Press Service News Agency, 2011. [Online]. Available: $<$ http://www.ipsnews.net/2011/02/zimbabwe-filteringfact- from- fiction- about-diy-water-treatment/

[10] Hsieh S. T, Lin T. F, \& Wang G. S., "Bio-degradation of MIB and geosmin with slow sand filters", Journal of Environmental Science and Health Part A, 45(8), 951957, 2010.

[11] Joubert E., Pillay D, \& Balakrishna P., "Visualization of the microbial colonization of a slow sand filter using an Environmental Scanning Electron Microscope", Electronic Journal of Biotechnology, 11(2), 2008.

[12] Centre for Affordable Water and Sanitation Technology, "Filtration sand for Bio-sand filter", 2008. [Online]. Available:http://biosandfilters.info/technical/filtrationsand-biosand-filter-2008.

[13] Mwabi J. K, Mamba B. B., \& Momba M. N., "Removal of waterborne bacteria from surface water and groundwater by cost-effective household water treatment systems (HWTS): A sustainable solution for improving water quality in rural communities of Africa", Water SA, 39(4), 00-00, 2013.

[14] Abudi, Z. N., "The effect of sand filter characteristics on removal efficiency of organic matter from grey water", Al-Qadisiya Journal for Engineering Sciences, 4(2), 143155, 2011.

[15]Ellis, V, "Slow sand filtration", CRC Critical Reviews in Environmental Control, 5(4), 315-354, 1984. 


\section{International Journal of Science and Research (IJSR) \\ ISSN (Online): 2319-7064}

Index Copernicus Value (2013): 6.14 | Impact Factor (2014): 5.611

[16] Centre for Affordable Water and Sanitation Technology, "Bio-sand Filter Manual: Design, Construction, \& Installation". [2009]. Available: https://www.calvin.edu/academic/engineering/seniordesign/SeniorDesign0910/team02/web/Biosand_Manual_English.pdf

[17] Centre for Affordable Water and Sanitation Technology, "Introduction to Drinking Water Quality Testing training manual", [2009]. Available: http://www.cala.ca/sampling/9_CAWST-Intro-toDrinking-Water-Quality-Testing.pdf

[18] World Health Organization, "Chemical Safety of Drinking-water: Assessing Priorities for Risk Management",[2007].Available:http://whqlibdoc.who.int /publications/2007/9789241546768_eng.pdf 